\title{
Orthographic Awareness through Orthographic Fast-Mapping of Children with Low-Reading- Achievement in Lower Grades in Elementary School
}

\author{
A Reum Kim, Rowon Kang, Young Tae Kim \\ Department of Communication Disorders, Ewha Womans University, Seoul, Korea
}

Correspondence: Young Tae Kim, PhD Department of Communication Disorders, Ewha Womans University, 52 Ewhayeodae-gil, Seodaemun-gu, Seoul 03760, Korea

Tel: $+82-2-3277-2120$

Fax: +82-2-3277-2122

E-mail: youngtae@ewha.ac.kr

Received: July 5, 2019

Revised: August 8, 2019

Accepted: August 19, 2019

This study was supported by the Ministry of Education of the Republic of Korea and the National Research Foundation of Korea (No. NRF2018S1A3A2075274).

\begin{abstract}
Objectives: This study compared the orthographic awareness ability through fast mapping between children who are reading at a low-achieving level and normal children in the lower grades of elementary school. Methods: The participants of the study were 16 low reading achievers (LRA group) and 16 typically developing children (TD group), for a total of 32 children. To identify the orthographic awareness ability of the children, an orthographic fast-mapping (OFM) task was used. The OFM task was analyzed by using a two-way mixed ANOVA according to the group and degree of wordlikeness. A Pearson correlation coefficient was performed to identify any associations of the orthographic awareness ability and linguistic factors according to each group. Finally, to discover error type patterns from the OFM task, the error type was analyzed. Results: First, our results showed that orthographic awareness has a significant main effect of group. Also, the main effect of the degree of wordlikeness were only significant in the orthographic production task. Second, static correlation was found only in the writing abilities of the TD group. For the LRA group, static correlations appeared in all areas except for vocabulary. Third, the analysis of the error type pattern of the OFM task between groups showed a high error rate in the order of visual similarity, phonetic similarity, and mixing. Conclusion: This study was able to compare the characteristics of low reading achievers and normal children by evaluating their orthographic awareness ability belonging to metalinguistic awareness. So these findings could be used as basic data for the mediation of orthographic awareness abilities of low reading achievers.
\end{abstract}

Keywords: Orthographic awareness, Orthographic fast-mapping, Low reading achievement
읽기와 쓰기는 의사소통에서 중요한 수단인 동시에, 학습에 밑 바탕이 되는 언어능력이다. 특히 문어(written language)에 대한 영 향력이 커지는 학령초기 아동들에게는 더욱 중요한 능력이다. 최 근 읽기와 쓰기의 연구들을 살펴보면, 메타언어인식과 관련지어 설 명하는 경우가 많아지고 있다. 메타언어인식(metalinguistic awareness)이란 언어구조를 고려하고 조작하는 것으로(Chung, 2016), 학 령기에 막 접어들어 글자를 배우기 시작하는 아동은 이를 적용하 는 학습 과정을 거치게 된다(Lazo, Pumfrey, \& Peers, 1997). 메타언 어인식에는 음운인식(phonological awareness), 철자인식(ortho- graphic awareness), 형태인식(morphological awareness) 등이 있는 데, 이 중 음운인식(Biemiller \& Boote, 2006), 철자인식(Wolter, Wood, \& D'zatko, 2009) 등이 철자 발달의 예측 지표로 보고되고 있다. 이렇게 각각의 능력들은 문해능력을 습득할 때 서로 상호관 계가 있으며, 읽기와쓰기 기능에 영향을 준다고 본다. 이 중 철자인 식은 우리 기억 속에 저장되어 있는 구어를 문어의 형식으로 표현 하는 패턴이나 방법에 관한 정보를 말한다(Apel, 2011).

Apel (2011)은 철자인식을 심상 문자소와 철자패턴 지식으로 나 누어 설명하는데, 이중 심상 문자소(mental graphemic representa- 
tion, MGRs)는 장기기억 속에 저장된 단어의 심적 표상(mental representation)을 의미한다. 심상 문자소는 문해력 발달의 초기 단 계 때 발달하는 기술인데(Apel, Masterson, \& Brimo, 2012), 아동 은 단어의 철자에 대한 표상을 빠른의미연결(fast mapping) 과정으 로 심상 문자소를 발달시키고, 잘 발달된 심상 문자소를 통해 단어 를 읽거나쓸 때, 의식적인 노력 없이도 가능하게 하는 것이다(Wolter \& Apel, 2010).

즉, 친숙한 낱말의 경우 하나의 덩이로 인식이 되어 훨씬 빨리 단 어를 읽어 낼 수 있으며, 이런 과정을 통해 글을 더 쉽고 빠르게 읽 어 나갈 수 있다. 쓰기에서도 마찬가지이다. 글자와 대응하는 소리 와의 관계를 알고, 해당하는 소리를 글자 형태로 바꾸는 과정을 통 해 자동적인 글자 쓰기가 이루어진다. 특히 초등학교에 입학하면 서, 즉 단어를 읽고 쓰기 시작하면서부터는 일견 단어(sight word) 가 증가하고, 점점 자동적으로 글을 읽고 쓸 때에 높은 정확도를 보 이게 된다. 여기서 적용되는 개념이 바로 철자인식인 것이다.

이렇게 Henbest와 Apel (2018)은 아동의 문어에 대한 빠른의미 연결 능력이 읽기와 쓰기 수행력과 관련이 있다고 설명한다. 따라 서, 아동은 단어와 단어의 철자에 대한 표상을 재빨리 연결하면서 철자인식을 발달시키고, 이렇게 발달된 철자인식 능력은 아동이 단 어를 읽거나 쓸 때 별도의 어려움이 없도록 도움을 준다(Wolter \& Apel, 2010). 그러나 이 과정에서 언어적인 어려움을 가진 아동들은 언어 자체의 어려움에 더하여 시간적인 지연과 인지적인 부담이 더 욱 증가하기 때문에 더 낮은 수행력을 보인다고 보고된다(Gray, 2005). 특히, 읽기부진 아동은 읽기와 쓰기의 어려움을 겪는데, 그 에 따른 요인으로 철자에 대한 인식이 느린 이유를 뽑고 있으며 (Yang \& Lee, 2016), 읽기부진 아동의 시각적인 처리와 주의집중의 결함(August \& Garfinkel, 1990) 또한 빠른의미연결 과제에서의 낮 은 수행력을 설명하는 요인으로 연결될 수 있다.

빠른의미연결 과제는 아동의 다른 언어 지식의 영향을 줄이고자 비단어를 사용하는 경우가 많은데, 최근 비단어를 사용한 과제가 비단어의 특성에 의해 과제 수행에 영향을 받을 수 있다는 연구가 나오고 있다(Bae \& Yim, 2018). 그 중 단어유사성 정도에 따라 과제 수행력이 달라진다는 연구들이 보고되는데(Vitevitch \& Luce, 2004), 단어유사성(wordlikeness)이란 하나의 비단어를 구성하는 소리들이 실제 단어들의 소리구조와 얼마나 유사한 정도를 나타내 는지에 대한 것으로, 비단어와 음운구조가 유사한 어휘를 생각해 내기 위하여 자신의 어휘지식을 사용하기 때문에 비단어가 실제 단어와 유사할수록 정확도가 높아진다고 한다(Gathercole, Willis, Emslie, \& Baddeley, 1991). 따라서, 본 연구에서는 철자 빠른의미연 결 과제를 통해 읽기부진 아동의 철자인식 특성을 확인하고, 단어
유사성의 변인에 따른 일반아동과 읽기부진 아동의 철자인식 능력 에차이가 있는지 살펴보고자 하였다.

문해 초기 아동의 표상능력을 발달시키기 위해서는 메타언어인 식들이 서로 상호작용하며 발달하면서 문해발달을 촉진하게 되는 데, 각 지식의 영향력이 발달 단계마다 다를 수 있다(Apel et al., 2012; Barber, 2013). 음운인식과 철자인식은 유치원 혹은 초등학교 저학년 때 급속도로 발전하며(Berninger, Abbott, Nagy, \& Carlisle, 2010), 중학년에 이르렀을 때 형태인식과 어휘력의 증진을 보인다고 보고된다(Rispens, McBride-Chang, \& Reitsma, 2008). 그러나, 이 러한 지식들의 불완전한 습득은 학습장애나 읽기부진의 아동들 경우 학습의 어려움을 줄수 있을 것이다.

앞선 연구들을 살펴보면, 철자인식 능력 발달에서 관련 깊은 요 인으로는 음운인식이 있으며(Goswami, 1992), 철자인식과 더불어 음운인식 능력은 읽기와 쓰기에서도 중요한 변인으로 뽑고 있다. 소 리를 조작하고 분석하는 과정을 통해 음소와 글자를 더 자연스럽 게 연결시킬 수 있기 때문이다. 그리고 연령이 증가될수록 어휘지식 능력 또한 단어와 문장을 읽고 쓰는 과정에서 영향력이 점점 커질 것이라 설명한다(Apel, 2009). 적절한 의미지식은 철자인식 능력과 함께 학령기 전반 아동의 철자 발달에 중요한 영향을 미치게 된다.

또한, 읽기발달 단계 중 철자법적 읽기 단계에서는 시각적으로 낱말을 재인하게 되는데, 이때 아동은 글자의 순서나 패턴을 사용 하여 글자를 읽게 되며(Catts \& Kamhi, 2005), 음운적인 단위가 아 닌 단어를 전체 단위로 인식하여 비음운적 철자 전략을 사용하게 된다(Goldsworthy, 2003). 이러한 선행연구들을 바탕으로 현재 국 내에서 읽기와 철자인식을 함께 관련지어 설명하는 연구들이 많이 이루어지고 있다. 그리고 철자인식은 말소리에 맞는 글자를 연결하 여 써야 하는 과정이기 때문에 쓰기에서도 필수적인 능력이다 (Masterson \& Apel, 2007). 특히나 우리나라 한글은 자소와 음소의 대응이 규칙적인 언어에 속하기 때문에, 철자인식을 통하여 자동 화된 철자쓰기를 경험할 수 있게 된다. Kim \& Petscher (2011)의 연 구에서도 철자지식이 쓰기에 중요한 영향을 미친 것을 확인할 수 있다. 그러나 읽기에 비해 쓰기에 관한 국내연구는 아직 부족한 실 정이다. 그렇기에 본 연구에서는 메타언어인식에 속하는 철자인식 과 음운인식 및 어휘력과의 상관성을 살펴보고, 더불어 읽기 및 쓰 기능력과도 그 관련성을 확인해보고자 하였다.

종합적으로, 본 연구는 철자인식 능력이 급속도로 발달하는 초 등학교 저학년 읽기부진 아동과 일반아동을 대상으로 빠른의미연 결을 통한 철자인식 능력을 비교해보고자 하였다. (1) 집단 간 철자 빠른의미연결 과제(비단어 철자쓰기, 비단어 철자확인)에서 단어 유사성 정도(높음, 낮음)에 따른 철자인식 능력이 유의한차이를 보 
이는지 확인하고, (2) 측정된 철자인식 능력과 상관을 보이는 요인 (음운인식, 어휘력, 해독, 철자쓰기)을 확인하고자 하였다. 그리고 (3) 철자인식 과제 중 비단어 철자확인 과제에서 집단별로 오류유 형 양상(시각적 유사성, 음운적 유사성, 혼합)을 비교하여 살펴보 고자하였다.

\section{연구방법}

\section{연구대상}

본 연구는 서울 및 수도권에 위치한 초등학교 1-2학년에 재학 중 인 읽기부진 아동 16 명(1학년 8명, 2학년 8명)과 일반아동 16 명(1학 년 8명, 2학년 8명), 총 32명을 대상으로 연구를 진행하였다. 읽기부 진 아동은 (1) 주양육자 혹은 담임교사 보고에 의해 읽기 학습에 어 려움이 있다고 보고되는 아동 중에, (2) 한국 비언어지능검사 제2판 (Korean version of Comprehensive Test of Nonverbal IntelligenceSecond Edition, K-CTONI-2; Park, 2014)의 도형 척도 결과 85 이 상이고, (3) 한국어 읽기검사(Korean Language-based Reading Assessment, KOLRA; Pae, Kim, Yoon, \& Jang, 2015)에서 읽기지수 2 (해독+읽기이해+읽기 유창성)가 90 이하로, 읽기 저성취 모델 기준 $25 \%$ 이하에 속하며(Shaywitz et al., 1992), (4) 시각 및 청각, 행동 및 정서 등에 장애가 없는 아동으로 선정하였다. 일반아동은 (1) 주양 육자 혹은 담임교사 보고에 의해 정상 발달로 보고되는 아동 중에, (2) 한국 비언어지능검사 제2판(K-CTONI-2)의 도형 척도 결과 85 이상이고, (3) 한국어 읽기검사(KOLRA)에서 읽기지수 2 (해독+읽 기이해+읽기 유창성)가 91 이상으로 규준 정상범위에 속하며, (4) 시각 및 청각, 행동 및 정서 등에 장애가 없는 아동으로 선정하였다.

본 연구에 참여한 대상자가 집단별로 표집이 잘 이루어졌는지 확 인하고자 독립표본 $t$-검정을 실시하였다. 그 결과, 읽기부진 아동 집 단과 일반아동 집단의 평균 월령은 각각 85.5 개월 $(\mathrm{SD}=6.37), 86.37$ 개월 $(\mathrm{SD}=6.14)$, 비언어 지능지수의 평균은 각각 $99.59(\mathrm{SD}=12.52)$, $104.75(\mathrm{SD}=9.94)$ 으로 집단 간 통계적으로 유의한 차이를 보이지 않았다. 읽기지수 평균은 각각 $52.87(\mathrm{SD}=15.7), 104.31(\mathrm{SD}=7.24)$ 로 집단에 따른 읽기지수의 차이는 통계적으로 유의하였다 $(t(30)=$ $8.43, p<.01)$. 읽기지수 하위검사 영역들을 통해 아동의 세부적인 읽기능력을 살펴본 결과, 읽기부진 아동 집단의 해독 원점수 평균 은 $23.68(\mathrm{SD}=23.44)$, 읽기이해 원점수 평균은 $1.68(\mathrm{SD}=2.18)$, 그 리고 읽기유창성 원점수 평균은 $8.12(\mathrm{SD}=5.82)$ 이었다. 일반아동 집단의 해독 원점수 평균은 $67.12(\mathrm{SD}=2.49)$, 읽기이해 원점수 평 균은 $10.62(\mathrm{SD}=3.49)$, 읽기유창성 원점수 평균은 $24.26(\mathrm{SD}=7.63)$ 인 것으로 나타났다. 대상자 정보는 다음 Table 1과 같다.
Table 1. Participants' characteristics

\begin{tabular}{lccc}
\hline & LRA (N=16) & TD (N=16) & $t$ \\
\hline Age (mo) & $85.5(6.37)$ & $86.37(6.14)$ & .020 \\
Nonverbal intelligence $^{\mathrm{a}}$ & $99.59(12.52)$ & $104.75(\mathrm{SD} 9.94)$ & 3.45 \\
Reading $^{\mathrm{b}}$ & $52.87(15.7)$ & $104.31(7.24)$ & $8.43^{* *}$ \\
\hline
\end{tabular}

Values are presented as mean (SD).

$\mathrm{LRA}=$ low reading achievement children; $\mathrm{TD}=$ typically developing children.

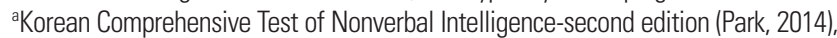

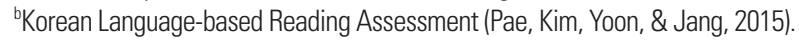
${ }^{* *} p<.01$.

\section{연구 과제 및 절차}

연구절차

본 실험은 서울 및 수도권에 위치한 지역아동센터 또는 아동의 집을 방문하여 검사자와 아동이 일대일로 독립된 조용한 공간에서 진행되었다. 대상자 선정을 위한 기초 검사와 본 연구 과제를 포함 하여 총 2회기로 나누어 실시하였다. 선별검사(K-CTONI-2, KOL$\mathrm{RA}$ )를 통해 읽기부진 아동과 일반아동으로 나누어 참여 아동을 선정하였으며, 기초 검사에서 연구대상으로 선정된 아동에게 본 연 구의 실험 과제(철자 빠른의미연결 과제, 수용·표현어휘력검사(Receptive \& Expressive Vocabulary Test, REVT; Kim, Hong, Kim, Jang, \& Lee, 2009), 아동 간편 읽기 및 쓰기발달검사)를 실시하였다.

\section{철자 빠른의미연결 과제}

본 연구에서는 아동의 철자인식 능력을 측정하기 위해 Henbest 와 Apel (2018)의 철자 빠른의미연결 과제(orthographic fast-mapping)를 바탕으로 한국어에 적합한 평가항목으로 수정, 개발하여 사용하였다. 과제는 12 개의 비단어로 구성하였다. 목표 단어는 단 어유사성 정도에 따라 단어유사성이 높은 비단어 6개와 단어유사 성이 낮은 비단어 6 개로 나누었다. 단어유사성에 따른 비단어 목록 은 Lee (2009)의 연구를 참고하여, 2-4음절에 해당하는 단어를 사 용하였다. 단어 목록은 실제 단어의 첫 음소만을 변경하여 구성하 였다. 단어유사성이 높은 비단어는 실제 단어의 첫 음소만 바꾸어 제작되었으며, 첫소리 자음은 조음방법 또는 조음위치가 같은 자 음으로 변형하였다. 단어유사성이 낮은 비단어는 단어유사성이 높 은 비단어와 평형을 이루도록 같은 자음을 포함하게 했고, 각 음절 의 초성 자음의 위치를 서로 바꾸어 음성적 균형을 맞추어 제작하 였다. 모음과 종성 자음은 바꾸지 않았다.

각 목표 단어는 '동동이의 물건을 소개합니다’라는 제목의 간단 한 이야기를 통해 아동에게 제시하였다. 동동이라는 캐릭터와 그 의 물건에 관한 내용으로 이루어졌으며, 이야기는 파워포인트 슬라 이드를 통해 2-4어절 문장으로 제시되었다. 하나의 목표 단어당 4 
개의 슬라이드로 구성된 이야기가 제공되었으며, 각 슬라이드에서 는 목표 단어를 포함하는 문장이 자막형식으로 제시되었다. 슬라 이드에는 목표 단어가 무의미 그림 자극으로 표현되었으며, 그림 자극은 Horst와 Hout (2016)의 연구에서 임의로 12개를 추출하였 다. 이야기의 각 슬라이드를 제시할 때 검사자는 문장을 다음과 같 이 들려주었다. (1) 물건의 이름(예: 이건 이구낭뿔에요), (2) 물건의 묘사(예: 이구낭뿔은 무거워요), (3) 물건을 가지고 하는 행동의 묘 사(예: 동동이가 이구낭뿔을 밀어요), (4) 물건의 위치 묘사(예: 이구 낭뿔이 의자 옆에 있어요). 아동은 각각의 목표 비단어가 있는 이야 기를 다 본 후, 비단어 철자쓰기 과제와 비단어 철자확인 과제를 수 행하였다.

비단어 철자쓰기 과제에서는 아동이 이전 4 개의 슬라이드를 통 해 학습이 된 목표 단어에 해당하는 그림을 보고 "이것의 이름이 무엇일까? 00이가 기억나는 대로 종이에 써보자”라는 검사자의 말 을 듣고 질문에 대한 답을 기록지에 연필로 쓰게 하였다. 쓰기 과제 후 아동은 확인 과제를 곧바로 수행하였다. 물건 그림 자극을 보고, “이번에는 이 물건을 뭐라고 부르는지 골라볼까?”라는 검사자 질 문에 4 개의 글자 보기 중 바른 철자로 표기된 단어를 선택하는 과 제이다. 4 개의 보기 단어는 다음과 같이 구성하였다. (1) 목표 단어 (예: 이구낭뿔), (2) 목표 단어와 시각적으로 유사한 단어(예: 이구당 불), (3) 목표 단어와 음운적으로 유사한 단어(예: 잏구낭뿔), (4) 혼 합 단어(예: 잏구당불), 혼합 단어는 나머지 3 개의 보기 단어에서 무작위로 1 음절씩 가지고 왔다. 문항의 예시는 Appendix 1에 제시 하였다.

철자 빠른의미연결 과제의 두 유형인 비단어 철자쓰기 과제와 비 단어 철자확인 과제는 각각 12 개의 문항으로 구성되며, 문항당 1 점 으로 총 12 점이다. 검사 결과는 정반응률(\%)로 측정하였으며, 아동 이 정반응한 응답의 수를 전체문항수로 나눈 후 100 을 곱하여 계 산하였다.

\section{아동 간편 읽기 및 쓰기발달검사}

아동의 음운인식 능력과 읽기능력, 쓰기능력을 검사하기 위하여 아동 간편 읽기 및 쓰기발달검사(Quick Assessment of Childhood Reading \& Writing, QRW; Kim et al., in press)를 실시하였다. 검사 는 음운조작 능력, 읽기, 쓰기의 3가지 영역으로 구성되어 있다. 음 운조작 능력 영역을 통하여 아동의 음운인식 능력을, 읽기 영역을 통하여 아동의 해독능력을, 쓰기 영역을 통하여 아동의 철자쓰기 능력을 측정하였다. 아동 간편 읽기 및 쓰기발달검사의 문항타당도 를 구하기 위해 언어병리학 박사과정 2 명을 대상으로 5 점 척도의 설 문을 진행한 결과, 음운조작 능력 영역은 평균 4.75 점, 읽기 영역은
4.75점, 쓰기 영역은 5점의 문항타당도 점수가 산출되었다(Ho, 2019).

음운조작능력 과제는 아동이 말소리를 듣고, 말소리를 서로 합 치거나 분리하는 등의 조작을 할 수 있는지를 평가하기 위한 과제 이다. 단어를 음절 수준으로 합성하고 분리하는 문항(예: '사'와 '자' 를 더하면?, ‘바다'는 무엇과 무엇으로 나누어질까요?) 4 개, 1 음절 단 어에 받침소리를 합성하고 $(\mathrm{CV}+\mathrm{C})$ 분리하는(CVC-C) 문항(예: '고' 에 'O'을 더하면?, '공'에서 ‘O'을 빼면?) 4 개, 1 음절 단어의 음소들을 합성하고 $(\mathrm{C}+\mathrm{V}+\mathrm{C})$ 분리하는(C,V,C) 문항(예: ' 'ᄀ'에 'ㄱ'에 'O'을 더 하면?, '공'은 무엇과 무엇과 무엇으로 나누어질까요?) 4 개로 구성되 어 있다. 아동이 자극을 듣지 못했거나 재요청하면 1 번 더 자극을 제시하였다. 또한, 자극을 제시할 때 음소의 소리 값을 제시한 후, 만약 아동이 문항 이해에 어려움이 있다고 판단될 시에 철자의 이 름을 제시하였다. 모든 문항은 예시 문항과 함께 설명되었다.

읽기 과제는 검사자의 설명과 함께 PPT 화면을 보고, 주어지는 글자소와 단어와 문장 자극을 읽게 된다. 글자소 읽기 문항 38 개(단 모음 8 개, 이중모음 11 개, 자음 19 개), 단어 읽기 문항 6 개(의미단어 3 개, 무의미단어 3 개), 문장 읽기 문항 9 개(의미단어로 구성된 문장 6개, 무의미단어로 구성된 문장 3 개)로 구성되어 있다.

쓰기 과제는 아동에게 기록지와 연필을 준 후 진행되며, 해당하 는 문항을 검사자는 불러주게 된다. 1 음절 쓰기 문항 11 개, 문장 쓰 기 9개로 구성된다. 각 문장은 2-4어절로 이루어져있고, 음운규칙 이 적용되는 어절을 포함한다. 음운규칙으로는 연음화, 7종성 법 칙, 유음화, 경음화, 격음화, 흘 탈락이 있다.

아동 간편 읽기 및 쓰기발달검사 중 음운조작능력 과제는 문항 당 1점으로, 총 12점으로 구성된다. 읽기 과제 중 글자소 읽기와 단 어 읽기는 각 문항당 1 점으로 채점되며, 문장 읽기의 경우 각 어절 당 1 점으로 채점되어 총점은 72 점이다. 쓰기 과제에서는 1 음절 단 어 쓰기는 문항당 1 점으로 채점되며, 문장 쓰기의 경우 각 어절당 1 점으로 채점되어 총점은 40 점이다. 여기서 문장 읽기 검사는 아동 이 음운규칙을 적용하여 읽는 것을 원칙으로 하였다. 음운조작능 력, 읽기, 쓰기 3 가지 영역 모두 검사 결과도 정반응률(\%)로 측정하 였으며, 아동이 정반응한 응답의 수를 전체문항수로 나눈 후 100 을 곱하여 계산하였다.

\section{통계적 처리}

연구문제에 대한 자료 분석은 SPSS Statistics version 23 (SPSS Inc., Chicago, IL, USA)를 사용하였으며, 통계적 처리는 다음과 같 다. 첫째, 집단 간 철자 빠른의미연결 과제에서 단어유사성 정도에 따른 철자인식 능력에 유의한 차이가 있는지 알아보기 위해 이원 
혼합분석(two-way mixed ANOVA)을 실시하였다. 둘째, 일반아동 집단과 읽기부진 아동 집단의 철자인식과 여러 요인 간의 상관관계 를 살펴보기 위해 Pearson 적률 상관계수를 실시하였다. 셋째, 집단 별 철자 빠른의미연결 과제에서 나타나는 오류유형 양상을 살펴보 기 위해, 오류유형별 오류비율을 산출하여 비교, 분석하였다.

\section{신뢰도}

연구의 신뢰도는 대상자의 $25 \%$ 를 무선 추출하여 철자 빠른의미 연결 과제와 아동 간편 읽기 및 쓰기발달검사 정반응률에 대한 평 가자 간 신뢰도를 구하였다. 연구자와 언어재활사 2 급 자격증을 소 지한 언어재활사 1 명이 정반응한 문항에 대하여 독립적으로 분석 하였다. 신뢰도는 점수가 일치한 문항수를 전체문항수로 나눈 다 음 100 을 곱하여 산출하였다. 본 연구 과제였던 철자 빠른의미연결 과제와 아동 간편 읽기 및 쓰기발달검사 중 음운조작능력, 읽기능 력, 쓰기능력 하위 과제 각각 $100 \%$ 의 신뢰도를 보였다.

\section{연구결과}

\section{집단 간 철자 빠른의미연결 과제에서 단어유사성 정도에 따른 철자인식 능력}

비단어 철자쓰기

집단 간 철자 빠른의미연결 과제(비단어 철자쓰기, 비단어 철자 확인)에서 단어유사성 정도(높음, 낮음)에 따른 철자인식 능력이 유의한 차이를 보이는지 확인하기 위해 이원혼합분석를 실시한 결 과, 집단에 따른 주효과가 통계적으로 유의하였다 $\left(F_{(1,30)}=199.944\right.$, $p<.001)$. 즉, 읽기부진 아동 집단 $(\mathrm{M}=33.33, \mathrm{SD}=24.34)$ 의 경우 일

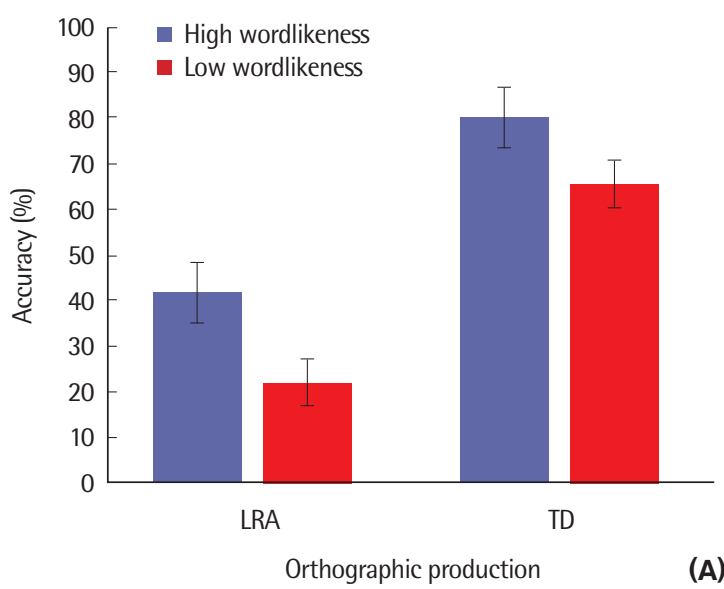

반 아동 집단(M=72.92, $\mathrm{SD}=17.34)$ 에 비해 비단어 철자 쓰기 과제 에서 유의하게 더 낮은 수행력을 보였다. 집단 내 요인인 단어유사성 정도에 따른 주효과도 통계적으로 유의하였다 $\left(F_{(1,30)}=15.904, p<\right.$ .001). 즉, 두 집단 모두 단어유사성이 높은 단어 $(\mathrm{M}=52.60, \mathrm{SD}=37.65)$ 에서 단어유사성이 낮은 단어 $(\mathrm{M}=38.02, \mathrm{SD}=32.02)$ 보다 통계적 으로 유의하게 더 높은 수행력을 보였다. 그러나, 단어유사성 정도 와 집단 간 상호작용은 통계적으로 유의하지 않았다. 결과는 Figure 1 과같다.

비단어 철자확인

집단에 따른 주효과가 통계적으로 유의한 것으로 나타났다 $\left(F_{(1,30)}\right.$ $=11.785, p<.001)$. 즉, 읽기부진 아동 집단 $(\mathrm{M}=73.44, \mathrm{SD}=20.91)$ 의 경우 일반아동 집단 $(\mathrm{M}=93.23, \mathrm{SD}=9.72)$ 에 비해 비단어 철자 확인 과제에서 유의하게 더 낮은 수행력을 보였다. 그러나, 집단 내 요인인 단어유사성 정도에 따른 주효과는 통계적으로 유의하지 않 았으며, 단어유사성 정도와 집단 간 상호작용 또한 통계적으로 유 의하지 않았다. 그 결과는 Figure 1과 같다.

\section{집단 간 철자인식과 음운인식, 어휘력, 해독, 철자쓰기와의 상관관계}

읽기부진 아동

두 집단의 철자인식 능력과 다양한 변인 간 상관관계를 살펴본 결과, 읽기부진 아동 집단에서 비단어 철자쓰기 과제는 음운인식 능력 $(r=.55, p<.05)$ 및 해독능력 $(\mathrm{r}=.84, p<.01)$ 및 철자쓰기능력 $(r=.89, p<.01)$ 과 유의한 정적 상관을 보였다. 그러나, 표현어휘력 및 수용어휘력과는 유의한 상관관계를 보이지 않았다. 비단어 철자

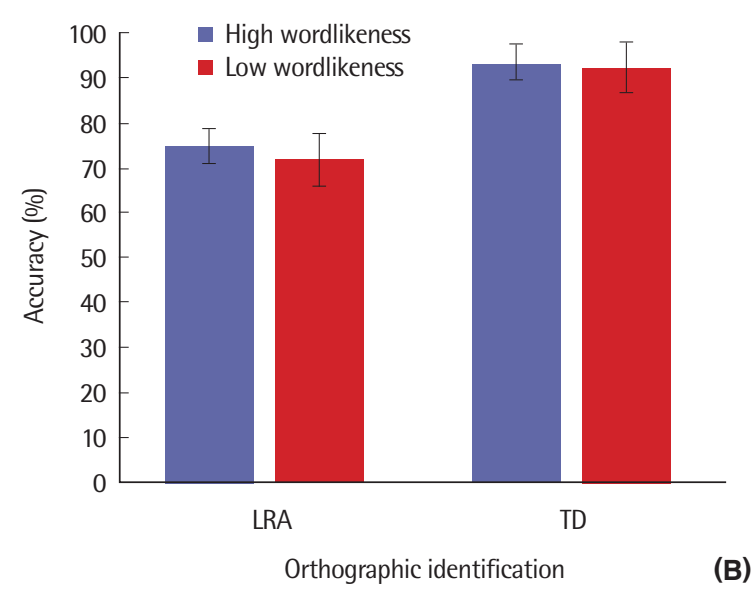

Figure 1. Performance of orthographic fast-mapping task by group and wordlikeness: (A) orthographic production and (B) orthographic identification. LRA= low reading achievement children; $T D=$ typically developing children. 
확인 과제 또한 음운인식능력 $(r=.69, p<.01)$ 및 해독능력 $(r=.811$ $p<.01)$ 및 철자쓰기능력 $(r=.721 p<.01)$ 과 유의한 정적 상관을 보 였다. 그러나, 표현어휘력 및 수용어휘력과는 유의한 상관관계를 보 이지 않았다. 즉, 비단어 철자쓰기 과제와 비단어 철자확인 과제 수 행력이 높을수록음운인식능력과 해독 및 철자쓰기 수행력도 높은 것으로 나타났다. 그 결과는 Table 2와 같다.

\section{일반아동}

분석 결과, 일반아동 집단에서 비단어 철자쓰기 과제는 철자쓰 기능력 $(r=.53, p<.05)$ 과 유의한 정적 상관을 보였다. 그러나, 음운 인식능력 및 표현어휘력 및 수용어휘력 및 해독능력과는 유의한 상관관계를 보이지 않았다. 비단어 철자확인 과제 또한 철자쓰기 능력 $(r=.57, p<.05)$ 과 유의한 정적 상관을 보였다. 그러나, 음운인 식능력 및 표현어휘력 및 수용어휘력 및 해독능력과는 유의한 상
관관계를 보이지 않았다. 즉, 비단어 철자쓰기 과제와 비단어 철자 확인 과제 수행력이 높을수록 철자쓰기 수행력도 높은 것으로 나 타났다. 그 결과는 Table 2와 같다.

\section{집단별 철자인식 과제 오류유형 분석}

철자인식 과제 중 철자 비단어 확인 과제에서 집단 간 오류유형 의 양상을 구체적으로 확인해보고자 오류유형별 오류비율을 산출 하여 비교, 분석을 실시하였다. 분석은 아동이 오반응한 문항을 3 가 지 보기 하위유형(시각적 유사성, 음운적 유사성, 혼합)으로 나누 어 진행하였다. 일반아동 집단이 오반응한 문항수는 총 13 문항이 었고, 읽기부진 아동 집단이 오반응한 문항수는 총 51 문항이었다.

집단별로 오류문항수와 출현율을 살펴본 결과, 일반아동 집단 의 경우 시각적 유사성 7/13 (53.84\%), 음운적 유사성 5/13 (38.46\%), 혼합 $1 / 13$ (7.69\%) 순으로 나타났다. 읽기부진 아동 집단의 경우에

Table 2. Correlation among measures of orthographic fast-mapping, phonological awareness, vocabulary, decoding and spelling between groups

\begin{tabular}{|c|c|c|c|c|c|c|c|c|}
\hline & $\begin{array}{c}\text { Orthographic } \\
\text { awareness } \\
\text { (production) }\end{array}$ & $\begin{array}{c}\text { Orthographic } \\
\text { awareness } \\
\text { (identification) }\end{array}$ & $\begin{array}{c}\text { Phonological } \\
\text { awareness }\end{array}$ & $\begin{array}{l}\text { Expressive } \\
\text { vocabulary }\end{array}$ & $\begin{array}{l}\text { Receptive } \\
\text { vocabulary }\end{array}$ & Decoding & Spelling & $\begin{array}{l}\text { LRA group } \\
\qquad(\mathrm{N}=16)\end{array}$ \\
\hline $\begin{array}{l}\text { Orthographic awareness } \\
\text { (production) }\end{array}$ & - & $.65^{* *}$ & $.55^{*}$ & -.060 & .02 & $.84^{* *}$ & $.89 * *$ & $33.33(24.32)$ \\
\hline $\begin{array}{l}\text { Orthographic awareness } \\
\text { (identification) }\end{array}$ & $.60^{*}$ & - & $.69^{* *}$ & .11 & .15 & $.81^{* *}$ & $.72^{* *}$ & 73.44 (20.91) \\
\hline Phonological awareness & .03 & .09 & - & .17 & .07 & $.75^{* *}$ & .62 & 44.79 (17.96) \\
\hline Expressive vocabulary & .25 & .26 & .26 & - & $.54^{*}$ & -.010 & .07 & 79.06 (11.88) \\
\hline Receptive vocabulary & .06 & .05 & .37 & $.69^{* *}$ & - & .10 & .19 & $76.50(13.75)$ \\
\hline Decoding & .25 & .01 & .36 & $.62^{*}$ & $.62^{*}$ & - & $.82^{* *}$ & 59.20 (28.92) \\
\hline Spelling & $.53^{*}$ & $.57^{*}$ & .14 & $.66^{* *}$ & $.54^{*}$ & $.62^{*}$ & - & $29.53(18.82)$ \\
\hline TD group $(\mathrm{N}=16$ ) & $72.92(17.34)$ & $93.23(9.72)$ & $91.15(6.43)$ & $101.25(16.02)$ & $97.00(13.52)$ & $92.36(6.88)$ & $75.47(14.44)$ & \\
\hline
\end{tabular}

Values are presented as correlation coefficient or mean (SD).

The correlation coefficient of the LRA group above the diagonal, and the correlation coefficient of the TD group below the diagonal are presented. $\mathrm{LRA}=$ low reading achievement children; $\mathrm{TD}=$ typically developing children .

${ }^{*} p<.05,{ }^{* *} p<.01$.

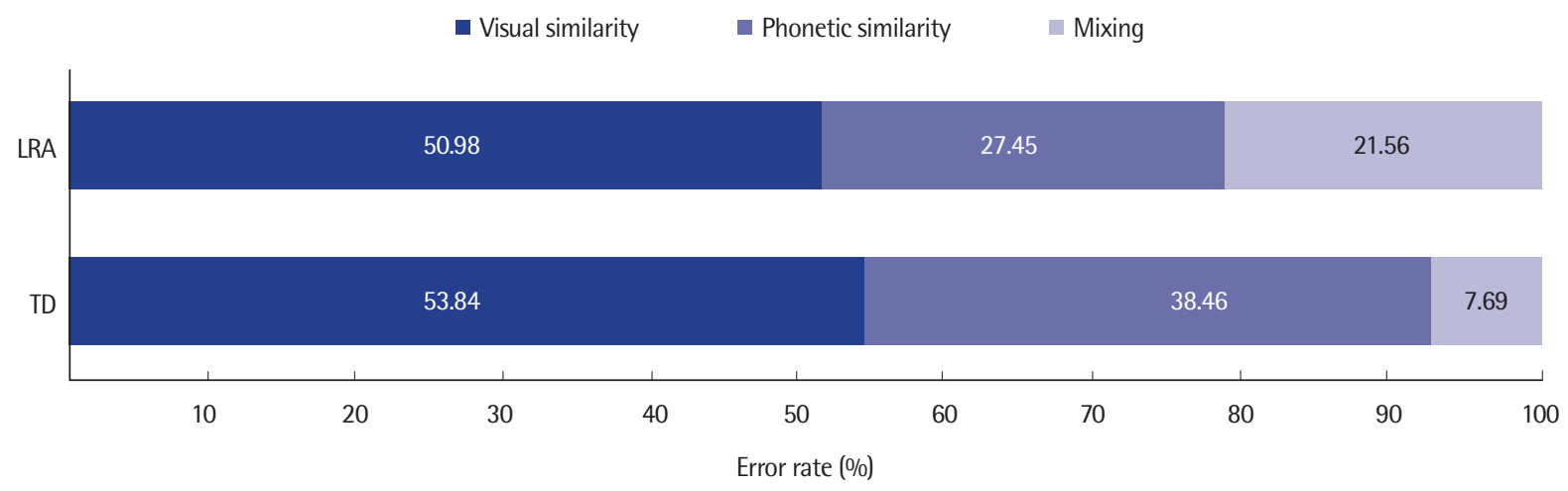

Figure 2. Orthographic awareness task error type pattern.

$\mathrm{LRA}=$ low reading achievement children; $\mathrm{TD}=$ typically developing children. 
는 시각적 유사성 26/51 (50.98\%), 음운적 유사성 14/51 (27.45\%), 혼 합 11/51 (21.56\%) 순의 출현율을 보였다. 즉, 두 집단 모두 시각적 유 사성, 음운적 유사성, 혼합 순으로 오류유형 양상을 보였으며, 이 중 시각적 유사성이 가장 두드러진 오류유형이었다. 집단별 오류유형 비교를 Figure 2에 제시하였다.

\section{논의 및 결론}

\section{집단 간 철자 빠른의미연결 과제에서 단어유사성 정도에 따른 철자인식 능력}

집단 간 철자 빠른의미연결 과제를 통한 철자인식능력 연구 결 과, 비단어 철자쓰기 과제와 비단어 철자확인 과제 모두 집단의 주 효과가 나타났다. 이는 읽기부진 아동이 철자인식에 대한 수행력이 유의미하게 낮았다는 선행연구와 일치하는 결과이다(Kim, 2016; Seo, 2001). 읽기부진 아동은 해독 전략이 부족하여 단어와 문장을 읽고, 문장 속 개별 단어를 확인하는 과정에도 어려움을 보인다고 하였다(Byun \& Kim, 2008). 그로 인해 과제 문맥상황 안에서 새로 운 어휘를 습득하는 빠른의미연결 방식 또한 어려웠을 것으로 판 단된다(Paul \& Norbury, 2012). 이런 읽기부진 아동의 다양한 언어 적 약점들이 이들의 철자인식 과제 수행력에 영향을 미쳤다고 예측 해볼 수 있으며, 철자능력 이외에도 읽기부진 아동의 음운처리 과 정, 시각적인 처리와 주의집중, 기저의 작업기억과 인지처리과정 등 의 결함 또한 영향을 끼칠 수 있었을 것이다.

본 연구에서 단어유사성 정도에 따른 주효과는 비단어 철자쓰 기 과제의 결과에서 선행연구(Henbest \& Apel, 2018)와 일치하였 다. 아동은 단어유사성이 높은 단어에서 더 좋은 수행력을 보였으 며, 이는 단어유사성 효과가 나타났다고 할 수 있다. 단어유사성이 높은 비단어일수록 음운구조가 유사한 친숙한 어휘 표상이 활성 화면서, 자신의 어휘지식을 활용한다고 보기 때문이다(Gathercole et al., 1991). 이때 비단어와 비슷한 음운적 이웃이 활성화되면서 (Marslen-Wilson, 1987) 그 어휘적 표상이 음운작업기억의 부담을 줄일 수 있었던 것이다. 읽기부진 아동 역시 일반아동 집단보다 수 행력은 저조했으나, 단어유사성 효과가 확실하게 작용하는 것을 확 인할 수 있었다. 그러나, 철자 비단어 확인 과제의 결과, 단어유사성 효과가 나타나지 않았다. 이는 일반아동 집단에게 과제의 난이도 가 낮아 천정효과(ceiling effect)가 나타났고, 이에 일반아동 집단 은 단어유사성 정도와 상관없이 대부분 만점이 많았던 것으로 설 명되어질 수 있다. 읽기부진 아동 집단의 경우도 비단어 철자확인 과제에서 비단어 철자쓰기 과제보다 수행력은 더 높았으나, 단어유 사성의 영향보다는 주어진 다른 보기 자극 유형에 더 영향을 받았
다고 할수 있다.

단어유사성 정도와 집단 간 상호작용은 비단어 철자쓰기 과제 와 비단어 철자확인 과제 모두 나타나지 않았다. 이는 일반아동 집 단과 읽기부진 아동 집단 모두 단어유사성 정도에 영향을 받는 양 상이 비슷하다고 볼 수 있다. 비단어 철자쓰기 과제의 경우, 두 집단 모두 단어유사성이 높을수록 수행력이 좋았으며, 비단어 철자확 인 과제의 경우, 두 집단 모두 단어유사성에 영향을 받지 않았다.

\section{집단 간 철자인식과 음운인식, 어휘력, 해독, 철자쓰기와의 상관관계}

철자인식과 음운인식, 어휘력, 해독, 철자쓰기와의 상관관계를 살펴본 결과, 읽기부진 아동의 경우 음운인식능력과 해독능력 및 철자쓰기능력과 유의한 상관관계를 보였으며, 일반아동 집단의 경 우, 철자쓰기능력과 유의한 상관관계를 보였다.

메타언어인식과 관련된 선행연구들을 토대로 살펴보면, 읽기부 진 아동 집단은 일반아동과 유사한 발달 양상을 보이는 것을 알 수 있다. 아동의 초기 문해발달을 촉진하는 언어학적 각 지식의 영향 력을 살펴보면, 음운인식과 철자인식은 유치원 혹은 초등학교 저학 년 때 급속도로 발전하며(Berninger et al., 2010), 중학년에 이르렀 을 때 형태인식과 어휘력의 증진을 보인다고 하였다(Rispens et al., 2008). 즉, 본 연구대상이였던 초등학교 1-2학년 읽기부진 아동은 이 시기에 음운인식과 철자인식을 함께 발달시키고 있으며, 그 지식 을 읽기 및 쓰기에 활용하고 있는 것으로 해석할 수 있다. 그러나초 등학교 1-2학년의 일반아동 철자발달에 있어 이미 음운인식은 학령 전기에 발달을 완성시켰으며, 초등학교에 입학하면서부터는 철자 인식이 읽기 및 쓰기에 주된 활용방식이 되는 것을 확인할 수 있다.

흥미롭게도 연구결과에서 일반아동 집단은 표현어휘력과 수용 어휘력이 읽기 및 쓰기능력과 정적 상관을 보이는 것을 확인할 수 있었다. 이는 읽기와 쓰기능력이 어휘지식을 활용하여 발달하기 시 작했다는 점을 시사한다. 이에 비해 읽기부진 아동은 표현어휘력 과 수용어휘력 모두 읽기 및 쓰기능력과 상관을 보이지 않았다. 즉, 이들의 전반적인 언어능력이 일반 초등학교 저학년보다 학령전기 에 가깝다고 볼 수 있다. 따라서, 아직은 형태인식 혹은 어휘지식보 다는 철자인식, 특히 음운인식도 함께 활용하고 있는 단계라고 유 추해 볼 수 있다. 결과적으로 집단 간 상관관계 양상은 조금 다르게 나타났지만 메타언어인식 발달 단계와 연결지어 살펴본다면 두 집 단 모두 같은 양상의 방식으로 설명될 수 있다.

더불어 일반 아동 집단에서 음운인식과 상관관계를 보이지 않았 던 이유는 기존 음운인식과 관련된 국내연구에서는 다른 언어권에 비하여 우리나라 초등학교 1학년 학생은 철자발달에 있어 음운인 
식의 영향력이 크지 않다는 연구와(Ahn, 2010), 국내 음운인식 연구 에서 어린 연령일수록 수행력이 낮다고 볼 수 있다는 결과(Je, 2014) 와도 같은 맥락으로 볼수 있다.

\section{집단별 철자 빠른의미연결 과제 오류유형 양상}

일반아동과 읽기부진 아동 집단의 철자 빠른의미연결 과제 중 비단어 철자확인 과제에서 오류유형을 비교, 분석한 결과, 두 집단 모두 시각적 유사성, 음운적 유사성, 혼합 순으로 오류비율이 나타 났으며, 두 집단 모두 비슷한 양상을 보였다.

시각적 단어재인에 영향을 주는 정보는 크게 음운적 속성과 시 각적 속성으로 나눌 수 있으며, 심성어휘집 안에 있는 단어에 접근 하는 경로가 무엇인지에 따라 음운재부호화통로 가설(phonological recoding route; Lesch \& Pollatsek, 1993), 시각부호통로 가설 (visual route or lexical route; Humphreys \& Evett, 1985), 이중통로 가설(dual route; Coltheart, 1978) 등의 가설이 있다. 이 중에서 이 중통로 가설은 표기경로(orthographic route)와 음운경로(phonological route)의 경로를 갖고 있는데, 표기경로는 시각적인 정보를 바탕으로 심성어휘집과 연결된 경로이고 음운경로는 음운적인 정 보를 바탕으로 심성어휘집과 연결된다고 설명하고 있다. 국내연구 에 따르면 일관적이지는 않지만, 대개 한글은 이중경로를 통해 단 어재인이 일어난다고 설명하고 있다(Tae, Lee, \& Lee, 2015; Yi, 1996).

대부분의 단어들을 표기경로를 통해 강한 연결 강도로 빠르게 처리되지만, 저빈도 단어나 특정한 경우(불규칙 등)에서는 음운경 로를 통해 단어가 처리되는 것이다. 이런 경우, 음운정보 간 충돌이 발생하여 과제 수행에서 반응 시간이 느려지고 오류율이 높아진 다. 즉, 아동은 친숙한 낱말은 글자 자극 자체를 통해 시각적으로 철 자 표상을 떠올리는 경로를 사용하게 되지만, 친숙하지 않은 낱말 이 경우 철자를 일일이 소리와 대응해가며, 음운부호로 해독해야 하는 과정을 거치게 된다. 다시 말해, 한글 처리 과정에서는 시각적 인 정보를 중심으로 처리되며 음운정보는 특정한 상황에서 보조적 인 역할을 한다고 볼 수 있다.

이에 근거하여 살펴보면, 본 연구결과는 이중경로 가설 선행연 구들과 일치하는 결과라고 볼 수 있다(Tae et al., 2015; Yi, 1996). 아 동이 철자 빠른의미연결을 통해 비단어를 학습하면서 목표 단어를 반복적으로 봤기 때문에, 단어에 대한 철자 표상이 강한 연결을 이 루었으며, 머릿속에 저장된 철자 패턴으로 하나의 덩이로 인식하였 다고 볼 수 있다. 따라서 목표 단어와 전체적인 윤곽이 비슷한 시각 적 유사성의 보기 유형은 단어재인 과정에서 큰 영향을 미쳤던 것 이다. 즉, 두 집단 모두 어휘를 처리할 때 시각적 속성에 대한 분석이 일차적으로 이루어졌으며, 이는 표기경로 중심으로 단어를 재인한
것으로 해석된다. 그 다음 음운적 정보는 부수적인 도움을 주는 요 소이기 때문에 시각적 유사성만큼의 오류비율을 보이진 않았던 것 이다. 그리고 혼합이 가장 낮았던 이유는 철자 표상을 확인했을 때 자신의 머릿속에 있는 어휘집에 대응하는 단어가 없었기 때문에 오 히려 빠르게 억제시킬 수 있었던 것으로 보인다.

종합해보면 본 연구는 메타언어인식에 속하는 철자인식 능력을 평가하여 읽기부진 아동과 일반아동의 특성을 비교 분석할 수 있 었으며, 더불어 다양한 메타언어인식과 읽기 및 쓰기능력과의 관련 성을 발견한 것에 의의가 있다. 또한, 문어형식의 빠른의미연결을 활용한 과제를 사용함으로써 학령기 아동의 철자인식을 다양하게 평가해볼 수 있는 가능성을 확인하였다. 또한, 단어유사성이라는 요인과 과제에서 나타난 오류유형 양상을 통해 읽기부진 아동의 철자인식능력 중재를 위한 기초자료로 활용할 수 있을 것이다.

본 연구의 제한점과 후속연구를 위한 제언은 다음과 같다. 첫째, 본 연구는 초등학교 1-2학년 읽기부진 아동 16명과 일반아동 16명 으로, 적은 수의 아동을 대상으로 진행하였기 때문에 연구결과를 일반화하기에는 어려움이 있다. 따라서 후속연구에서는 대상자의 수를 충분히 확보할 필요가 있다. 또한, 메타언어인식은 학령기 동 안 다양한 지식들이 서로 상호작용하며 지속적으로 발달한다. 때 문에 학년과 다양한 메타언어인식의 변인들을 추가하여 발달 양상 을 살펴보는 것도 필요해 보인다. 둘째, 본 연구에서는 철자인식, 음 운인식, 어휘력, 읽기, 쓰기검사를 같은 시기에 실시하여 그에 대한 상관관계를 살펴보았다. 그러나 이러한 변인들이 읽기 및 쓰기능력 을 얼마나 예측하는지 알아보기 위한 1년 혹은 그 이상 기간 동안 의 추적 연구가 필요할 것이다. 이러한 추적 연구를 통해 읽기부진 아동의 조기선별을 위한 시사점을 발견할 수 있을 것이다. 셋째, 본 연구에서는 철자인식검사와 관련하여 기저의 작업기억과 인지 처 리 과정 등에 대한 검사들을 진행하지 않았다. 따라서 후속연구에 서는 언어발달과 관련한 기저 기억능력 등을 같이 살펴보는 것도 의미 있을 것이다.

\section{REFERENCES}

Ahn, S. W. (2010). A study of relationship among phonological awareness, letter knowledge, letter-sound correspondence and age. The Korea Journal of Learning Disabilities, 8(1), 1-23.

Apel, K. (2009). The acquisition of mental orthographic representations for reading and spelling development. Communication Disorders Quarterly, 31(1), 42-52.

Apel, K. (2011). What is orthographic knowledge? Language, Speech, and 
Hearing Services in Schools, 42(4), 592-603.

Apel, K., Masterson, J. J., \& Brimo, D. (2012). Spelling assessment and intervention: a multiple linguistic approach to improving literacy outcomes. In A. G. Kamhi \& H. W. Catts (Eds.), Language and reading disabilities (3rd ed., pp. 226-243). Boston, MA: Pearson.

August, G. J., \& Garfinkel, B. D. (1990). Comorbidity of ADHD and reading disability among clinic-referred children. Journal of Abnormal Child Psychology, 18(1), 29-45.

Bae, K., \& Yim, D. (2018). The effect of linguistic knowledge and Korean phonotactic probability on nonword repetition and fast mapping ability. Communication Sciences \& Disorders, 23(2), 477-495.

Barber, A. (2013). Multilinguistic components of spelling: an overview. Perspectives on Language Learning and Education, 20(4), 124-128.

Berninger, V. W., Abbott, R. D., Nagy, W., \& Carlisle, J. (2010). Growth in phonological, orthographic, and morphological awareness in grades 1 to 6 . Journal of Psycholinguistic Research, 39(2), 141-163.

Biemiller, A., \& Boote, C. (2006). An effective method for building meaning vocabulary in primary grades. Journal of Educational Psychology, 98(1), 44-62.

Byun, C. S., \& Kim, G. S. (2008). The effects of teaching phonological awareness on word recognition in children with learning disabilities. Journal of Special Education: Theory and Practice, 9(3), 331-351.

Catts, H. W., \& Kamhi, A. G. (2005). Language and reading disabilities (2nd ed.). Boston, MA: Pearson.

Chung, B. J. (2016). Morphological awareness on derivational affixes and related variables in school-aged children (Doctoral dissertation). Ewha Womans University, Seoul, Korea.

Coltheart, M. (1978). Lexical access in simple reading tasks. In G. Underwood (Ed.), Strategies of information processing (pp. 151-216). New York, NY: Academic Press.

Gathercole, S. E., Willis, C., Emslie, H., \& Baddeley, A. D. (1991). The influences of number of syllables and wordlikeness on children's repetition of nonwords. Applied Psycholinguistics, 12(3), 349-367.

Goldsworthy, C. L. (2003). Developmental reading disabilities: a language based treatment approach. Clifton Park, NY: Thomson.

Goswami, U. (1992). Annotation: Phonological factors in spelling development. Journal of Child Psychology and Psychiatry, 33(6), 967-975.

Gray, S. (2005). Word learning by preschoolers with specific language impairment: effect of phonological or semantic cues. Journal of Speech, Language \& Hearing Research, 48(6), 1452-1467.
Henbest, V. S., \& Apel, K. (2018). Orthographic fast-mapping across time in 5-and 6-year-old children. Journal of Speech, Language, and Hearing Research, 61(8), 2015-2027.

Ho, Y. J. (2019). Influence of vocabulary abilities on multicultural families children's phonological manipulation skill, word recognition ability and letter writing ability (Master's thesis). Ewha Womans University, Seoul, Korea.

Horst, J. S., \& Hout, M. C. (2016). The Novel Object and Unusual Name (NOUN) database: a collection of novel images for use in experimental research. Behavior Research Methods, 48(4), 1393-1409.

Humphreys, G. W., \& Evett, L. J. (1985). Are there independent lexical and nonlexical routes in word processing? An evaluation of the dual-route theory of reading. Behavioral and Brain Sciences, 8(4), 689-705.

Je, H. S. (2014). Effect of emergent literacy skills on monosyllable reading of children with typical development and mild intellectual disability (Doctoral dissertation). Ewha Womans University, Seoul, Korea.

Kim, J. Y. (2016). Characteristics of reading related factors in subgroups with language learning disorders. Journal of Learner-Centered Curriculum and Instruction, 16(6), 339-353.

Kim, Y. S., \& Petscher, Y. (2011). Relations of emergent literacy skill development with conventional literacy skill development in Korean. Reading and Writing, 24(6), 635-656.

Kim, Y. T., Hong, G. H., Kim, K. H., Jang, H. S., \& Lee, J. Y. (2009). Receptive \& expressive vocabulary test (REVT). Seoul: Seoul Community Rehabilitation Center.

Kim, Y. T., Je, H. S., Jung, K. H., Kim, Y. R., Pae, S., \& Kim, H. C. (in press). Quick Assessment of Childhood Reading and Writing (QRW).

Lazo, M. G., Pumfrey, P. D., \& Peers, I. (1997). Metalinguistic awareness, reading and spelling: roots and branches of literacy. Journal of Research in Reading, 20(2), 85-104.

Lee, H. J. (2009). The influences of number of syllables and wordlikeness on 3to 5-year-old Korean-English bilingual children's nonword repetition (Master's thesis). Ewha Womans University, Seoul, Korea.

Lesch, M. F., \& Pollatsek, A. (1993). Automatic access of semantic information by phonological codes in visual word recognition. Journal of Experimental Psychology: Learning, Memory, and Cognition, 19(2), 285-294.

Marslen-Wilson, W. D. (1987). Functional parallelism in spoken word-recognition. Cognition, 25(1-2), 71-102.

Masterson, J. J., \& Apel, K. (2007). Spelling and word-level reading: a multilinguistic approach. In A. G. Kamhi et al. (Eds.), Clinical decision making in developmental language disorders (pp. 249-266). Baltimore, MD: Paul H. 
Brookes Publishing.

Pae, S., Kim, M., Yoon, H. J., \& Jang, S. (2015). Korean Language Based Reading Assessment (KOLRA). Seoul: Hakjisa.

Park, H. (2014). Korean version of Comprehensive Test of Nonverbal Intelligence Second Edition (K-CTONI-2). Seoul: Mindpress.

Paul, R., \& Norbury, C. F. (2012). Language disorders from infancy through adolescence: listening, speaking, reading, writing, and communicating (4th ed.). St. Louis, MO: Elsevier.

Rispens, J. E., McBride-Chang, C., \& Reitsma, P. (2008). Morphological awareness and early and advanced word recognition and spelling in Dutch. Reading and Writing, 21(6), 587-607.

Seo, G. H. (2001). An overview of phonological processing in children with reading disability. Journal of Emotional \& Behavioral Disorders, 17(2), 4370.

Shaywitz, B. A., Fletcher, J. M., Holahan, J. M., \& Shaywitz, S. E. (1992). Discrepancy compared to low achievement definitions of reading disability: Results from the Connecticut Longitudinal Study. Journal of Learning Disabilities, 25(10), 639-648.
Tae, J., Lee, C., \& Lee, Y. (2015). The effect of the orthographic and phonological priming in Korean visual word recognition. Korean Journal of Cognitive Science, 26(1), 1-26.

Vitevitch, M. S., \& Luce, P. A. (2004). A web-based interface to calculate phonotactic probability for words and nonwords in English. Behavior Research Methods, Instruments, \& Computers, 36(3), 481-487.

Wolter, J. A., \& Apel, K. (2010). Initial acquisition of mental graphemic representations in children with language impairment. Journal of Speech, Language, and Hearing Research, 53(1), 179-195.

Wolter, J. A., Wood, A., \& D'zatko, K. W. (2009). The influence of morphological awareness on the literacy development of first-grade children. Language, Speech, and Hearing Services in Schools, 40(3), 286-298.

Yang, M. W., \& Lee, A. J. (2016). Influences of linguistic awareness on primary grade children's spelling abilities. Korea Journal of Learning Disabilities, 13(3), 67-90.

Yi, K. O. (1996). Phonological rules in oral reading of Korean. Korean Journal of Cognitive and Biological Psychology, 8(1), 1-24. 
Appendix 1. Example of orthographic fast-mapping task

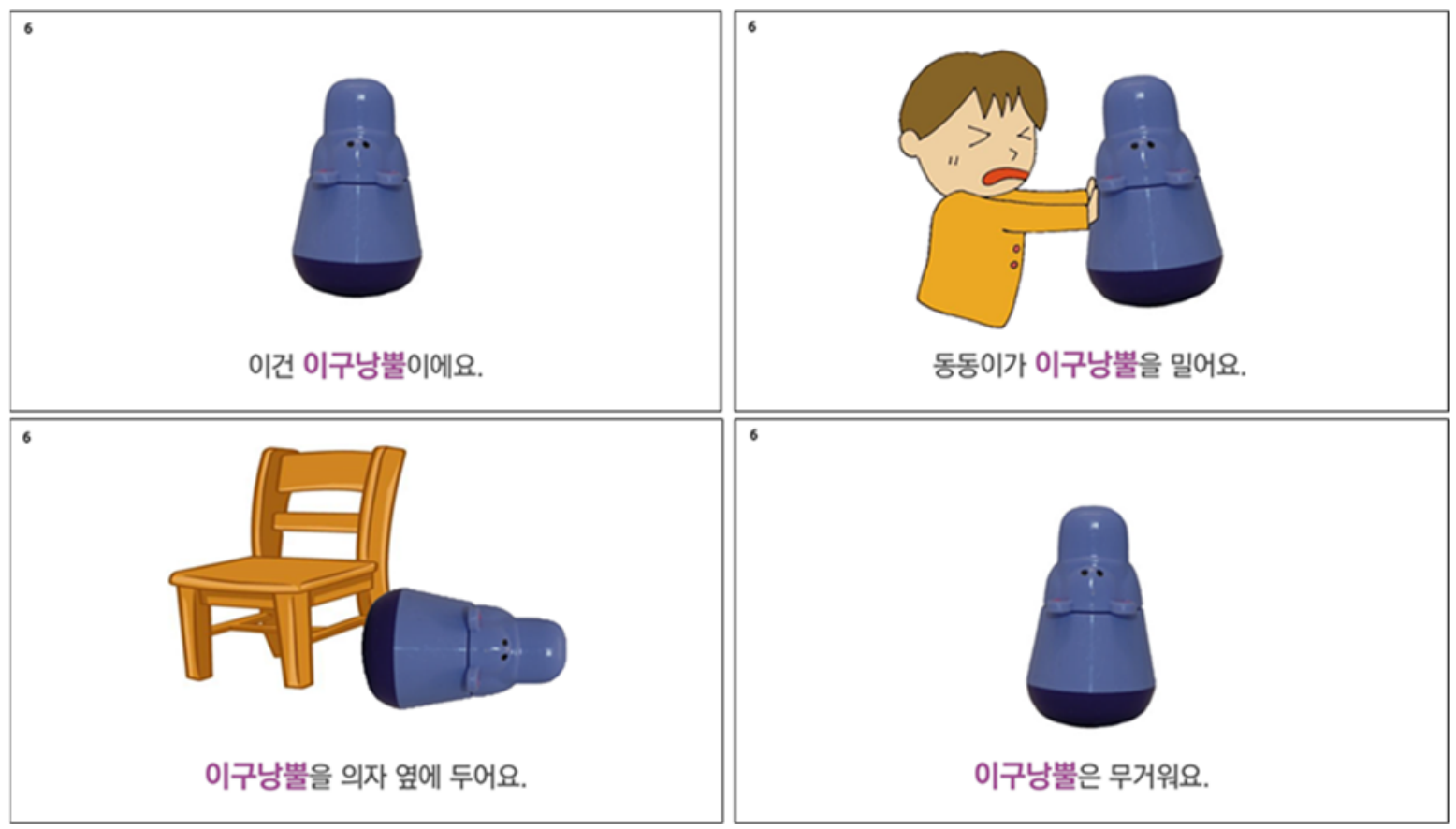




\section{국문초록}

\section{철자 빠른의미연결 과제를 통한 초등학교 저학년 읽기부진 아동의 철자인식 특성}

김아름 · 강로원 · 김영태

이화여자대학교 언어병리학과

배경 및 목적: 본 연구는 철자인식이 급속도로 발달하는 초등학교 저학년 읽기부진 아동과 일반아동을 대상으로 빠른의미연결을 통 한 철자인식 능력을 비교해보고자 하였다. 방법: 연구 대상은 초등학교 1-2학년 읽기부진 아동 16 명, 일반아동 16 명, 총 32 명이다. 철자 인식 검사는 철자 빠른의미연결 과제로 진행하였으며, 과제는 비단어 철자쓰기와 비단어 철자 확인으로 구성된다. 본 연구에서는 철자 인식 능력을 집단과 과제유형, 단어유사성 정도에 따라 분석하였으며 집단 간 음운인식, 어휘력, 해독, 철자 쓰기와의 상관을 분석하였 다. 또한, 집단별 과제에서의 오류유형 양상도 함께 살펴보았다. 결과: 첫 번째, 읽기부진 아동은 일반아동에 비해 철자인식 능력이 낮은 것으로 나타났다. 또한, 비단어 철자쓰기 과제에서 단어유사성 정도에 따라 수행력 차이가 나타났다. 두 번째, 일반아동 집단의 경우 쓰 기 능력에서만 정적 상관이 나타났으며, 읽기부진 아동 집단의 경우, 어휘력을 제외한 모든 영역에서 정적 상관이 나타났다. 세 번째, 두 집단 모두 시각적 유사성, 음운적 유사성, 혼합 순의 오류유형 양상을 보였다. 논의 및 결론: 본 연구는 메타언어인식에 속하는 철자인 식 능력을 평가하여 읽기부진 아동과 일반아동의 특성을 비교 분석할 수 있었으며, 더불어 다양한 메타언어인식과 읽기 및 쓰기 능력 과의 관련성을 발견한 것에 의의가 있다. 따라서 읽기부진 아동의 철자인식 능력 중재를 위한 기초자료로 활용할 수 있을 것이다.

핵심어: 철자인식, 철자 빠른의미연결, 읽기부진

본 연구는 2018년 대한민국 교육부와 한국연구재단의 지원을 받아 수행된 연구임(No. NRF-2018S1A3A2075274).

\section{참고문헌}

김영태, 제현순, 정경희, 김영란, 배소영, 김효창(출판준비중). 아동 간편 읽기 및 쓰기 발달 검사(Quick Assessment of Childhood Reading \& Writing). 김영태, 홍경훈, 김경희, 장혜성, 이주연(2009). 수용·표현어휘력검사(REVT). 서울: 서울장애인종합복지관.

김주영(2016). 하위유형별 언어학습장애 아동의 읽기 관련 요인 특성. 학습자중심교과교육연구, 16(6), 339-353.

박혜원(2014). 한국 비언어지능검사 2판(K-CTONI-2). 서울: 마인드프레스.

배경란, 임동선(2018). 언어적 지식과 한국어 음소배열확률이 비단어 따라말하기 및 빠른의미연결 능력에 미치는 영향. Communication Sciences \&

Disorders, 23(2), 477-495.

배소영, 김미배, 윤효진, 장승민(2015). 한국어 읽기검사(KOLRA). 서울: 학지사.

변찬석, 김길순(2008). 음운인식 훈련이 학습장애아의 단어재인에 미치는 효과. 특수교육저널: 이론과 실천, 9(3), 331-351.

서경희(2001). 읽기 장애아의 음운 처리 고찰. 정서·행동장애연구, 17(2),43-70.

안성우(2010). 4-7세 유아들의 낱자지식과 음운인식능력과의 관계에 관한 연구. 학습장애연구, 8(1), 1-23.

양민화, 이애진(2016). 학령기 초기 아동의 철자 기술에 미치는 언어학적 인식 능력의 영향력 변화. 학습장애연구, 13(3), 67-90.

이광오(1996). 한글 글자열의 음독과 음운규칙. 한국심리학회지: 인지 및 생물, 8(1), 1-24.

이현정(2009). 음절길이와 단어유사성이 3-5세 한국어-영어 이중언어아동의 비단어 따라말하기 수행에 미치는 영향. 이화여자대학교 대학원 석사 학위논문.

정부자(2016). 초등학교 저학년과 중학년 일반아동의 파생어 형태인식 발달 및 예측 변인 탐색. 이화여자대학교 대학원 박사학위논문.

제현순(2014). 초기 문해력 기술들이 일반아동 및 지적장애아동의 1 음절읽기 능력에 미치는 영향. 이화여자대학교 대학원 박사학위논문.

태진이, 이창환, 이윤형(2015). 한국어 시각 단어재인과정에서 음운정보와 표기정보의 역할. 인지과학, 26(1), 1-26.

호유진(2019). 어휘력 수준에 따른 중학년 다문화가정 아동의 음운 조작 능력과 낱말 재인 및 철자 쓰기 능력. 이화여자대학교 대학원 석사학위논문. 


\section{ORCID}

김아름(제1저자, https://orcid.org/0000-0003-1230-3386); 강로원(공동저자, https://orcid.org/0000-0001-6550-4208); 김영태(교신저자, https://orcid.org/0000-0003-1738-6862) 